\title{
Biomass Estimation of Dry Tropical Woody Species at Juvenile Stage
}

\author{
R. K. Chaturvedi, ${ }^{1}$ A. S. Raghubanshi, ${ }^{2}$ and J. S. Singh ${ }^{1}$ \\ ${ }^{1}$ Ecosystems Analysis Laboratory, Department of Botany, Banaras Hindu University, Varanasi 221005, India \\ ${ }^{2}$ Institute of Environment and Sustainable Development, Banaras Hindu University, Varanasi 221005, India
}

Correspondence should be addressed to R. K. Chaturvedi, ravikantchaturvedi10@gmail.com

Received 18 October 2011; Accepted 8 December 2011

Academic Editor: Krishna K. Moorthy

Copyright (C) 2012 R. K. Chaturvedi et al. This is an open access article distributed under the Creative Commons Attribution License, which permits unrestricted use, distribution, and reproduction in any medium, provided the original work is properly cited.

\begin{abstract}
Accurate characterization of biomass in different forest components is important to estimate their contribution to total carbon stock. Due to lack of allometric equations for biomass estimation of woody species at juvenile stage, the carbon stored in this forest component is ignored. We harvested 47 woody species at juvenile stage in a dry tropical forest and developed regression models for the estimation of above-ground biomass (AGB). The models including wood-specific gravity $(\rho)$ exhibited higher $R^{2}$ than those without $\rho$. The model consisting of $\rho$, stem diameter $(D)$, and height $(H)$ not only exhibited the highest $R^{2}$ value but also had the lowest standard error of estimate. We suggest that $\rho$-based regression model is a viable option for nondestructive estimation of biomass of forest trees at juvenile stage.
\end{abstract}

\section{Introduction}

For accurate estimation of carbon sink in the forest, a precise mapping of forest biomass at a fine resolution is required [1]. Generally, forest biomass is estimated by a common allometric equation which is generally applied over a large area [2]. Variety of factors such as age of stand, species, topography, environmental heterogeneity, and human disturbance, however, affect forest biomass. Therefore, a considerable uncertainty exists in the estimation of spatial distribution of biomass [3, 4]. Several authors [5-12] have published biomass estimations using species-specific allometric equations relating destructively measured tree biomass and field measured circumference at breast height $(\mathrm{CBH})$ or diameter at breast height $(\mathrm{DBH})$ for trees with $\mathrm{CBH}$ $>10 \mathrm{~cm}$. Recently, Singh et al. [13] have established allometric equations for both above- and below-ground components of three native species (diameter $<10 \mathrm{~cm}$ ) used for plantation in the Indian subcontinent. Most biomass equations have only $\mathrm{CBH}$ or $\mathrm{DBH}$ as estimator, causing a significant problem for regional-scale comparisons of tree biomass estimates. In order to explore the variations in biomass estimates due to environmental, structural, and compositional gradients, wood-specific gravity $(\rho)$ has been incorporated as a simple multiplication factor in diameter-based biomass equations based on tree diameter (e.g., [14-18]).

Individuals in small stem circumference class $(<10 \mathrm{~cm})$ comprise a significant proportion of tree population and have faster growth rate than the higher diameter class trees, but allometric equations for their biomass estimation are lacking. As a result, the carbon stored in the juvenile tree population is ignored. In this study, we measured aboveground biomass (AGB) of 47 woody species at juvenile stage, occurring in dry tropical forest, by harvest method and developed a multispecies regression model for the nondestructive estimation of AGB with the help of woodspecific gravity $(\rho)$, stem diameter $(D)$, and plant height $(H)$. Further, we observed the strength of similarity between the species-specific, actual harvested AGB, and the AGB estimated by the multispecies regression model.

\section{Materials and Methods}

We harvested 10 juvenile individuals of each of the 47 woody species in the dry deciduous forest $\left(21^{\circ} 29^{\prime}-25^{\circ} 11^{\prime} \mathrm{N}\right.$ lat. and $78^{\circ} 15^{\prime}-84^{\circ} 15^{\prime} \mathrm{E}$ long.) of Vindhyan highlands situated in 
TABLE 1: Range of stem diameter $(D)$, height $(H)$, and woodspecific gravity $(\rho)$ of the juvenile tree species harvested from the study site. $n=10$ per species.

\begin{tabular}{|c|c|c|c|c|}
\hline S. no. & Species & $\rho\left(\mathrm{g} \mathrm{cm}^{-3}\right)$ & $D(\mathrm{~cm})$ & $H(\mathrm{~cm})$ \\
\hline (1) & Acacia auriculiformis & $0.47-0.52$ & $0.5-3.1$ & $30.5-103.4$ \\
\hline (2) & Acacia catechu & $0.48-0.58$ & $0.6-2.9$ & $30.8-99.2$ \\
\hline (3) & Adina cordifolia & $0.34-0.38$ & $0.6-3.1$ & $31.4-112.6$ \\
\hline (4) & Albizia odoratissima & $0.47-0.57$ & $0.7-2.7$ & $30.7-94.5$ \\
\hline (5) & Anogeissus latifolia & $0.56-0.64$ & $0.6-3.1$ & $30.6-108.8$ \\
\hline (6) & Azadirachta indica & $0.52-0.58$ & $0.5-2.9$ & $31.6-98.3$ \\
\hline (7) & Bauhinia racemosa & $0.52-0.58$ & $0.9-3.1$ & $31.5-99.5$ \\
\hline$(8)$ & Boswellia serrata & $0.34-0.38$ & $0.6-2.8$ & $30.4-98.0$ \\
\hline (9) & Bridelia retusa & $0.48-0.56$ & $0.8-3.0$ & $30.7-98.6$ \\
\hline$(10)$ & Buchanania lanzan & $0.45-0.56$ & $0.7-2.9$ & $31.7-88.9$ \\
\hline (11) & Carissa spinarum & $0.52-0.57$ & $0.6-3.1$ & $30.6-89.7$ \\
\hline (12) & Cassia fistula & $0.51-0.56$ & $0.8-2.6$ & $30.4-91.0$ \\
\hline (13) & Cassia siamea & $0.53-0.59$ & $0.6-3.1$ & $30.5-111.7$ \\
\hline$(14)$ & Chloroxylon swietenia & $0.47-0.54$ & $0.7-3.1$ & $31.6-99.6$ \\
\hline$(15)$ & $\begin{array}{l}\text { Dendrocalamus } \\
\text { strictus }\end{array}$ & $0.45-0.49$ & $0.7-2.8$ & $60.8-196.0$ \\
\hline$(16)$ & $\begin{array}{l}\text { Diospyros } \\
\text { melanoxylon }\end{array}$ & $0.53-0.58$ & $0.5-3.1$ & $30.8-89.6$ \\
\hline$(17)$ & Elaeodendron glaucum & $0.51-0.57$ & $0.7-3.0$ & $30.5-99.4$ \\
\hline$(18)$ & Emblica officinalis & $0.53-0.58$ & $0.6-2.8$ & $30.6-117.0$ \\
\hline (19) & Flacourtia indica & $0.55-0.59$ & $0.7-3.1$ & $31.4-99.7$ \\
\hline$(20)$ & Gardenia latifolia & $0.48-0.53$ & $0.8-2.9$ & $30.5-98.3$ \\
\hline$(21)$ & Gardenia turgida & $0.51-0.55$ & $0.7-2.8$ & $31.6-98.0$ \\
\hline$(22)$ & Grewia hirsuta & $0.48-0.53$ & $0.6-3.1$ & $30.6-99.4$ \\
\hline$(23)$ & Grewia serrulata & $0.51-0.55$ & $0.8-2.8$ & $30.7-98.0$ \\
\hline$(24)$ & Hardwickia binata & $0.58-0.65$ & $0.8-2.9$ & $30.4-98.7$ \\
\hline$(25)$ & $\begin{array}{l}\text { Holarrhena } \\
\text { antidysenterica }\end{array}$ & $0.52-0.55$ & $0.6-2.8$ & $30.8-98.0$ \\
\hline$(26)$ & Holoptelea integrifolia & $0.52-0.58$ & $0.5-3.1$ & $31.4-99.4$ \\
\hline$(27)$ & $\begin{array}{l}\text { Hymenodictyon } \\
\text { excelsum }\end{array}$ & $0.48-0.54$ & $0.8-3.0$ & $30.8-99.5$ \\
\hline$(28)$ & Indigofera cassioides & $0.48-0.52$ & $0.7-2.9$ & $30.3-98.3$ \\
\hline (29) & $\begin{array}{l}\text { Lagerstroemia } \\
\text { parviflora }\end{array}$ & $0.52-0.57$ & $0.8-2.8$ & $31.2-98.0$ \\
\hline$(30)$ & Lannea coromandelica & $0.35-0.41$ & $0.6-3.1$ & $30.5-116.3$ \\
\hline$(31)$ & Lantana camara & $0.42-0.46$ & $0.8-2.8$ & $30.4-98.0$ \\
\hline (32) & Madhuca longifolia & $0.47-0.54$ & $0.7-2.9$ & $30.8-98.5$ \\
\hline$(33)$ & Miliusa tomentosa & $0.52-0.56$ & $0.6-3.1$ & $31.0-99.7$ \\
\hline (34) & Mitragyna parvifolia & $0.51-0.59$ & $0.7-2.9$ & $30.4-98.6$ \\
\hline$(35)$ & Nyctanthes arbortristis & $0.48-0.53$ & $0.7-3.1$ & $31.4-99.3$ \\
\hline$(36$ & Ougeinia oogenesis & $0.51-0.54$ & $0.6-3.1$ & $30.7-99.2$ \\
\hline (37) & $\begin{array}{l}\text { Pterocarpus } \\
\text { marsupium }\end{array}$ & $0.58-0.67$ & $0.6-2.7$ & $30.6-94.5$ \\
\hline$(38)$ & Schleichera oleosa & $0.51-0.54$ & $0.5-3.1$ & $30.8-99.6$ \\
\hline$(39)$ & $\begin{array}{l}\text { Schrebera } \\
\text { swietenioides }\end{array}$ & $0.51-0.58$ & $0.6-2.9$ & $31.6-98.4$ \\
\hline
\end{tabular}

TABle 1: Continued.

\begin{tabular}{|c|c|c|c|c|}
\hline \multicolumn{2}{|c|}{ S. no. Species } & \multirow{2}{*}{$\frac{\rho\left(\mathrm{g} \mathrm{cm}^{-3}\right)}{0.41-0.46}$} & \multirow{2}{*}{$\begin{array}{l}D(\mathrm{~cm}) \\
0.6-3.1\end{array}$} & \multirow{2}{*}{$\begin{array}{c}H(\mathrm{~cm}) \\
30.5-99.4\end{array}$} \\
\hline$(40)$ & $\begin{array}{l}\text { Semecarpus } \\
\text { anacardium }\end{array}$ & & & \\
\hline$(41)$ & Shorea robusta & $0.61-0.67$ & $0.5-2.9$ & $30.7-119.6$ \\
\hline$(42)$ & Soymida febrifuga & $0.53-0.58$ & $0.7-3.1$ & $31.7-98.8$ \\
\hline$(43)$ & Terminalia tomentosa & $0.61-0.67$ & $0.7-2.9$ & $30.7-98.5$ \\
\hline$(44)$ & Woodfordia fruticosa & $0.49-0.55$ & $0.8-2.9$ & $30.6-87.9$ \\
\hline$(45)$ & Zizyphus glaberrima & $0.48-0.55$ & $0.7-3.0$ & $31.4-98.5$ \\
\hline$(46)$ & Zizyphus nummularia & $0.52-0.56$ & $0.9-2.9$ & $31.5-98.7$ \\
\hline \multirow[t]{2}{*}{ (47) } & Zizyphus oenoplea & $0.47-0.53$ & $0.6-3.1$ & $30.4-89.4$ \\
\hline & Average & 0.53 & 1.90 & 67.8 \\
\hline
\end{tabular}

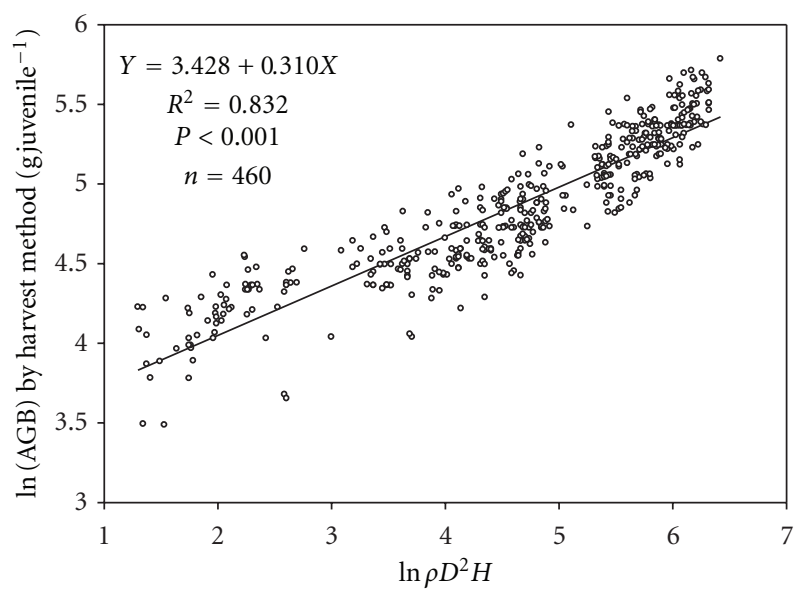

Figure 1: Relationships between the log transformed values of $\rho D^{2} \mathrm{H}$ and the $\log$ transformed values of above-ground biomass (AGB, g) estimated by harvest method for 46 juvenile tree species. $\rho$ : wood-specific gravity $\left(\mathrm{g} \mathrm{cm}^{-3}\right) ; D$ : stem diameter $(\mathrm{cm}) ; H$ : height $(\mathrm{cm})$.

TABLE 2: Regression models for estimating biomass of juvenile trees. SEE: Standard error of estimate. $Y$ : logarithm of above ground biomass $(\ln \mathrm{AGB}) ; X_{1}: \ln D^{2} ; X_{2}: \ln \rho D^{2} ; X_{3}: \ln D^{2} H ; X_{4}:$ $\ln \rho D^{2} H$.

\begin{tabular}{lcccc}
\hline S. no. & Model & $R^{2}$ & SEE & $P$ \\
\hline$(1)$ & $Y=3.344+0.443 X_{1}$ & 0.809 & 0.196 & $<0.001$ \\
$(2)$ & $Y=2.666+0.432 X_{2}$ & 0.824 & 0.188 & $<0.001$ \\
$(3)$ & $Y=3.204+0.315 X_{3}$ & 0.819 & 0.191 & $<0.001$ \\
$(4)$ & $Y=3.428+0.310 X_{4}$ & 0.832 & 0.184 & $<0.001$ \\
\hline
\end{tabular}

Sonebhadra District of Uttar Pradesh, India. The juvenile individuals represented the population of each species in the forest at juvenile stage. The juvenile stage was defined as individuals having $\geq 30 \mathrm{~cm}$ height and $<10 \mathrm{~cm}$ stem circumference $10 \mathrm{~cm}$ above the ground surface. Height $(H)$ and stem circumference of each individual were recorded. Leaves were plucked and stem and branches were cut into small pieces. From each individual plant, wood samples were taken and $\rho$ was estimated following the method described by Chaturvedi et al. [14]. For the estimation of above-ground dry biomass 

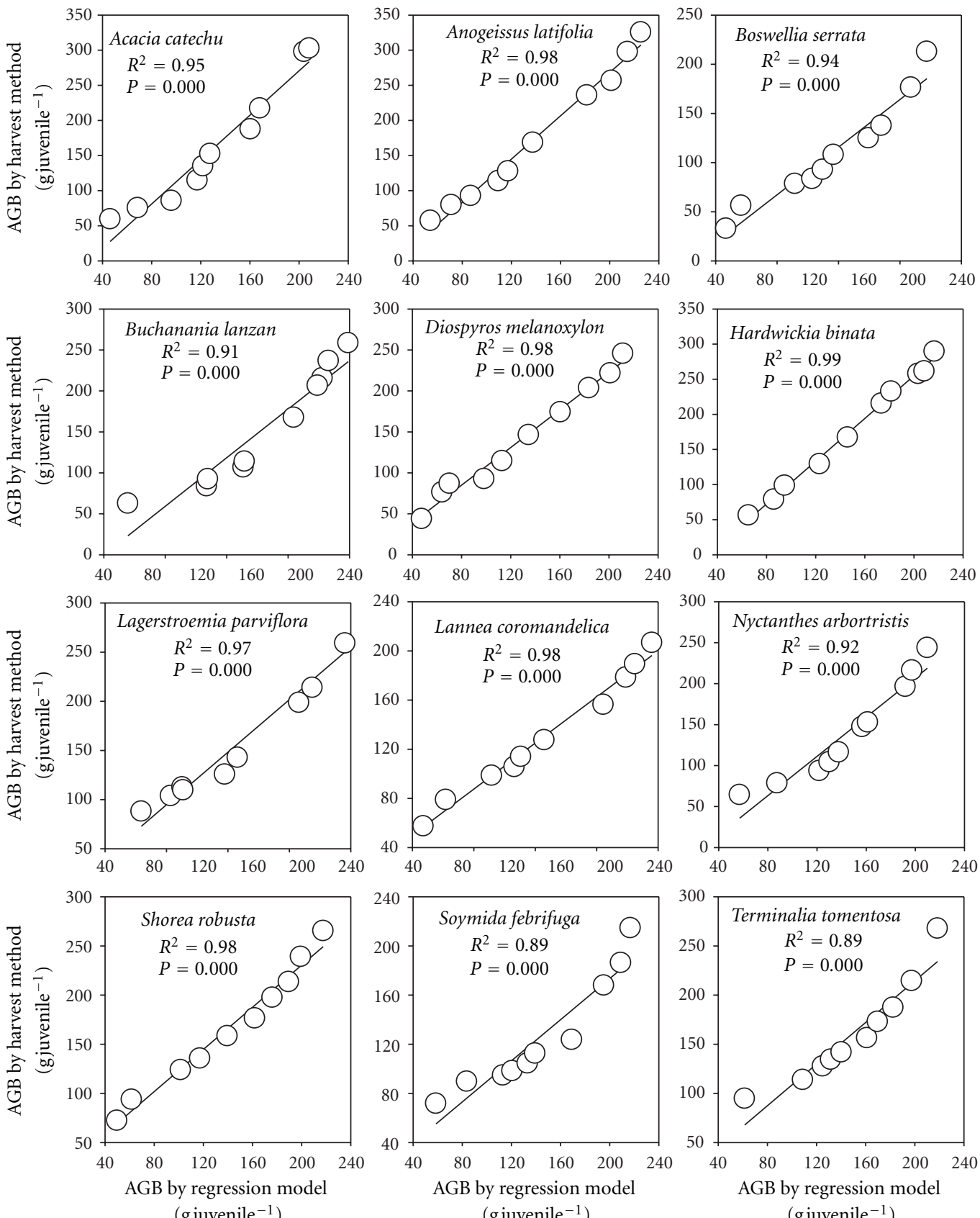

FIGURE 2: Relationships between the above ground biomass (AGB) of the dominant juvenile tree species estimated by allometric equation and by harvest method.

(AGB), stem, branches, and leaves of each individual plant were dried in an oven at $80^{\circ} \mathrm{C}$ to constant weight. Data of all the species were pooled to develop regression models for the estimation of AGB on the basis of $D, H$, and $\rho$. For Dendrocalamus strictus, a separate model was developed. The best model was selected on the basis of $R^{2}$ and standard error of estimate. To check for the strength of relationship between AGB estimated for individual species by harvest method and that by the multispecies regression model, we regressed the harvest data of 12 dominant species against the estimates obtained through the newly developed model.

\section{Results and Discussion}

Ranges of $\rho, D$, and $H$ are shown in Table 1 . The values of measured $\rho$ reported in this study for juvenile trees are lower compared to those reported for mature trees of dry tropical forest $[19,20]$ and were higher for individuals with greater $D$. The regression models developed for the estimation of AGB are reported in Table 2. All these models explained more than $80 \%$ variability in AGB. The models including $\rho$ exhibited higher $R^{2}$ than those without $\rho$. The model consisting of $\rho$, $D$, and $H$ not only exhibited the highest $R^{2}$ value but also had the lowest standard error of estimate. 
We selected model 4 (see Table 2 ) as the most suitable model for the estimation of AGB of the juvenile woody species. Figure 1 shows strong correlation between harvested AGB and the estimator used in our model. Average AGB for all species excluding Dendrocalamus strictus estimated by harvest method was $138 \pm 2.26 \mathrm{~g}_{\text {juvelile }}^{-1}$ and that from regression model was $141 \pm 2.83 \mathrm{~g}_{\text {juvelile }}{ }^{-1}$. The model was also validated against harvested AGB of 12 dominant species of the forest (Figure 2). In Dendrocalamus strictus, the $H$ of plant was greater at a particular $D$ as compared to other species, making its value an outlier in the regression analysis. Therefore, we developed a separate model for Dendrocalamus strictus as $Y=2.487+0.414 X, R^{2}=0.967$, and $P<0.001$, where $Y=\ln \mathrm{AGB}$ and $X=\ln \rho D^{2} H$. For this species, the average AGB estimated by harvest method was $110 \pm 16.6 \mathrm{~g}$ juvelile $^{-1}$ and that from regression model was $112 \pm 19.1 \mathrm{~g}$ juvelile . $^{-1}$.

Chave et al. [21] also reported $\rho$ as an important predictive variable in different regression models developed for the estimation of AGB in tropical forests. Since the density of carbon per unit volume is highly correlated with $\rho$, it has direct implication for estimating ecosystem carbon storage and fluxes $[15,16,22,23]$. Muller-Landau [24] found significant difference in $\rho$ of tropical trees among sites. For the estimation of sitewise variation of biomass of a woody species at juvenile stage, a common site-specific $\rho$ value was obtained by harvesting few individuals and can be applied in the regression model for all the individuals of the species at a site. Thus, the regression model can become a viable option for nondestructive estimation of biomass of forest tree component at juvenile stage.

Most of the current studies of biomass estimation are focused on relatively large trees $(>10 \mathrm{~cm}$ diameter) ignoring the contribution of other forest components particularly juvenile woody species. In some situations, these types of studies could be justified; however, in forests such as dry tropical forests which are continuously under high anthropogenic disturbance, the biomass estimation of low diameter trees becomes particularly important. Sagar and Singh [25] have reported $85 \%$ of individuals in the dry tropical forest being at juvenile stage at any given time. Therefore, to understand the carbon dynamics, it is necessary to include juveniles in biomass estimation programmes.

\section{Acknowledgments}

The authors thank the Ministry of Environment and Forests, Government of India for the financial support. J. S. Singh is supported by NASI senior scientist scheme.

\section{References}

[1] R. A. Houghton, "Aboveground forest biomass and the global carbon balance," Global Change Biology, vol. 11, no. 6, pp. 945958, 2005.

[2] R. A. Houghton, "Revised estimates of the annual net flux of carbon to the atmosphere from changes in land use and land management 1850-2000," Tellus, vol. 55, no. 2, pp. 378-390, 2003.
[3] C. L. Goodale, M. J. Apps, R. A. Birdsey et al., "Forest carbon sinks in the Northern Hemisphere," Ecological Applications, vol. 12, no. 3, pp. 891-899, 2002.

[4] J. Y. Fang, S. Brown, Y. H. Tang, G.-J. Nabuurs, X. P. Wang, and H. H. Shen, "Overestimated biomass carbon pools of the northern mid- and high latitude forests," Climatic Change, vol. 74, no. 1-3, pp. 355-368, 2006.

[5] O. P. Chaturvedi and J. S. Singh, "The structure and function of pine forest in central himalaya. II. Nutrient dynamics," Annals of Botany, vol. 60, no. 3, pp. 253-267, 1987.

[6] Y. S. Rawat and J. S. Singh, "Structure and function of oak forests in central Himalaya. I. Dry matter dynamics," Annals of Botany, vol. 62, no. 4, pp. 397-411, 1988.

[7] S. Brown, A. J. R. Gillespie, and A. E. Lugo, "Biomass estimation methods for tropical forests with applications to forest inventory data," Forest Science, vol. 35, no. 4, pp. 881-902, 1989.

[8] L. Singh and J. S. Singh, "Species structure, dry matter dynamics and carbon flux of a dry tropical forest in India," Annals of Botany, vol. 68, no. 3, pp. 263-273, 1991.

[9] S. S. Bargali, S. P. Singh, and R. P. Singh, "Structure and function of an age series of Eucalypt plantations in central Himalaya. I. Dry matter dynamics," Annals of Botany, vol. 69, no. 5, pp. 405-411, 1992.

[10] N. Lodhiyal, L. S. Lodhiyal, and Y. P. S. Pangtey, "Structure and function of Shisham forests in central Himalaya, India: dry matter dynamics," Annals of Botany, vol. 89, no. 1, pp. 41$54,2002$.

[11] M. Segura and M. Kanninen, "Allometric models for tree volume and total aboveground biomass in a tropical humid forest in Costa Rica," Biotropica, vol. 37, no. 1, pp. 2-8, 2005.

[12] J. Návar, "Allometric equations for tree species and carbon stocks for forests of northwestern Mexico," Forest Ecology and Management, vol. 257, no. 2, pp. 427-434, 2009.

[13] V. Singh, A. Tewari, S. P.S. Kushwaha, and V. K. Dadhwal, "Formulating allometric equations for estimating biomass and carbon stock in small diameter trees," Forest Ecology and Management, vol. 261, no. 11, pp. 1945-1949, 2011.

[14] R. K. Chaturvedi, A. S. Raghubanshi, and J. S. Singh, "Nondestructive estimation of tree biomass by using wood specific gravity in the estimator," National Academy Science Letters, vol. 33, no. 5-6, pp. 133-138, 2010.

[15] B. W. Nelson, R. Mesquita, J. L. G. Pereira, S. G. A. de Souza, G. T. Batista, and L. B. Couto, "Allometric regressions for improved estimate of secondary forest biomass in the central Amazon," Forest Ecology and Management, vol. 117, no. 1-3, pp. 149-167, 1999.

[16] T. R. Baker, O. L. Phillips, Y. Malhi et al., "Variation in wood density determines spatial patterns in Amazonian forest biomass," Global Change Biology, vol. 10, no. 5, pp. 545-562, 2004.

[17] D. A. King, S. J. Davies, S. Tan, and N. S. M. D. Noor, "The role of wood density and stem support costs in the growth and mortality of tropical trees," Journal of Ecology, vol. 94, no. 3, pp. 670-680, 2006.

[18] T. M. Basuki, P. E. van Laake, A. K. Skidmore, and Y. A. Hussin, "Allometric equations for estimating the aboveground biomass in tropical lowland Dipterocarp forests," Forest Ecology and Management, vol. 257, no. 8, pp. 1684-1694, 2009.

[19] R. K. Chaturvedi, A. S. Raghubanshi, and J. S. Singh, "Carbon density and accumulation in woody species of tropical dry forest in India," Forest Ecology and Management, vol. 262, no. 8, pp. 1576-1588, 2011. 
[20] R. K. Chaturvedi, A. S. Raghubanshi, and J. S. Singh, "Plant functional traits with particular reference to tropical deciduous forests: A review," Journal of Biosciences, vol. 36, no. 5, pp. 963-981, 2011.

[21] J. Chave, C. Andalo, S. Brown et al., "Tree allometry and improved estimation of carbon stocks and balance in tropical forests," Oecologia, vol. 145, no. 1, pp. 87-99, 2005.

[22] S. Brown, "Estimating biomass and biomass change of tropical forests: a primer," F. A. O. Forestry Paper 134, Food and Agriculture Organization of the United Nations, Rome, Italy, 1997.

[23] P. M. Fearnside, "Greenhouse gases from deforestation in Brazilian Amazonia: net committed emissions," Climatic Change, vol. 35, no. 3, pp. 321-360, 1997.

[24] H. C. Muller-Landau, "Interspecific and inter-site variation in wood specific gravity of tropical trees," Biotropica, vol. 36, no. 1, pp. 20-32, 2004.

[25] R. Sagar and J. S. Singh, "Structure, diversity, and regeneration of tropical dry deciduous forest of northern India," Biodiversity and Conservation, vol. 14, no. 4, pp. 935-959, 2005. 

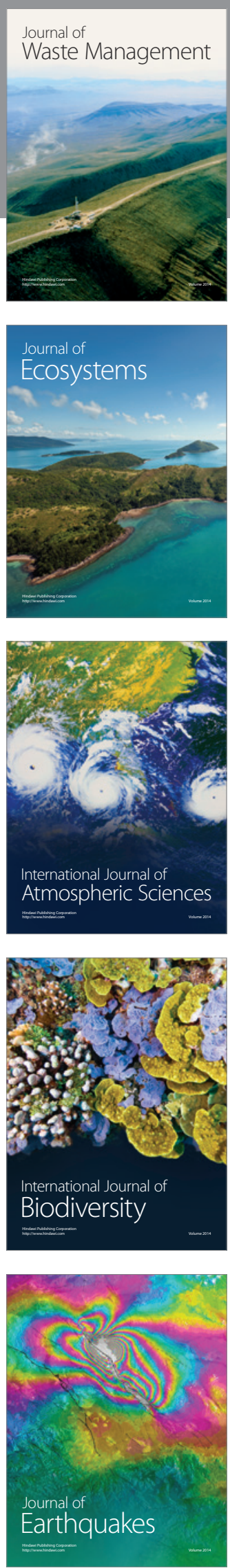
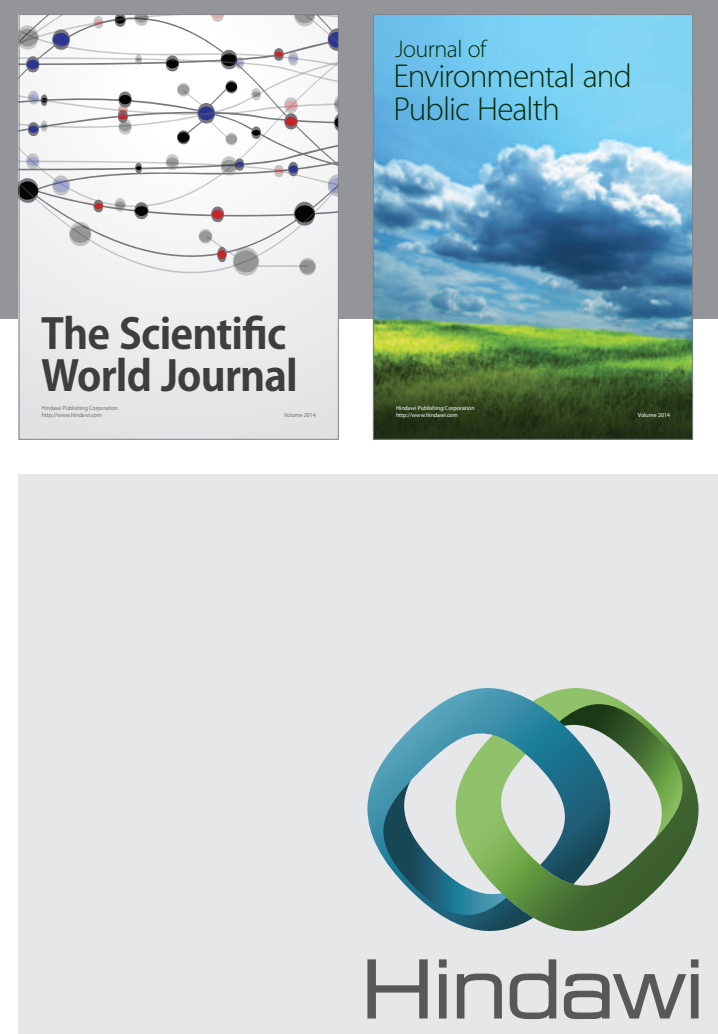

Submit your manuscripts at

http://www.hindawi.com
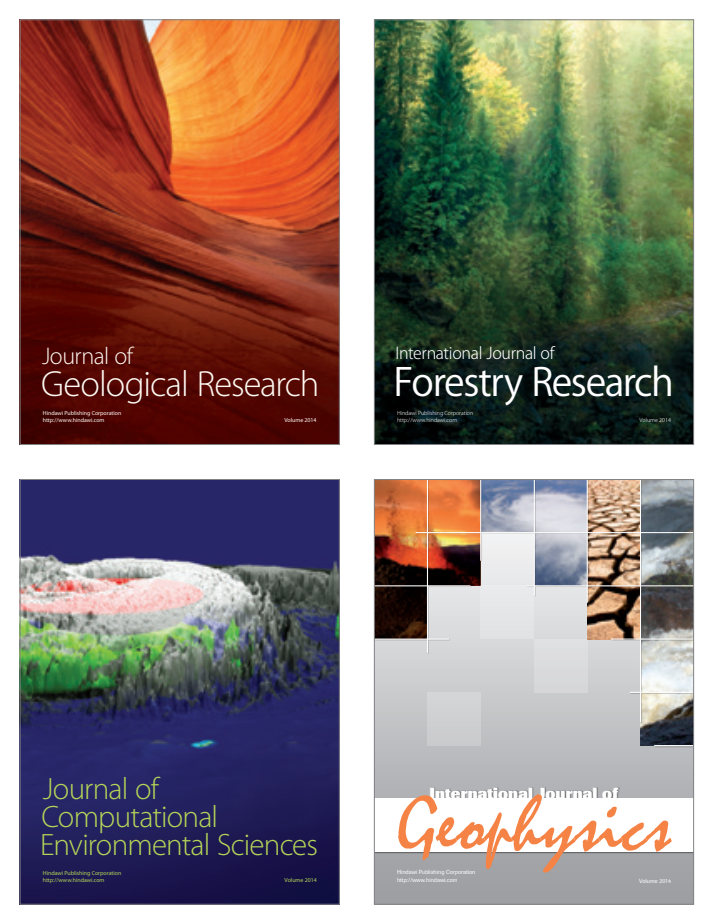
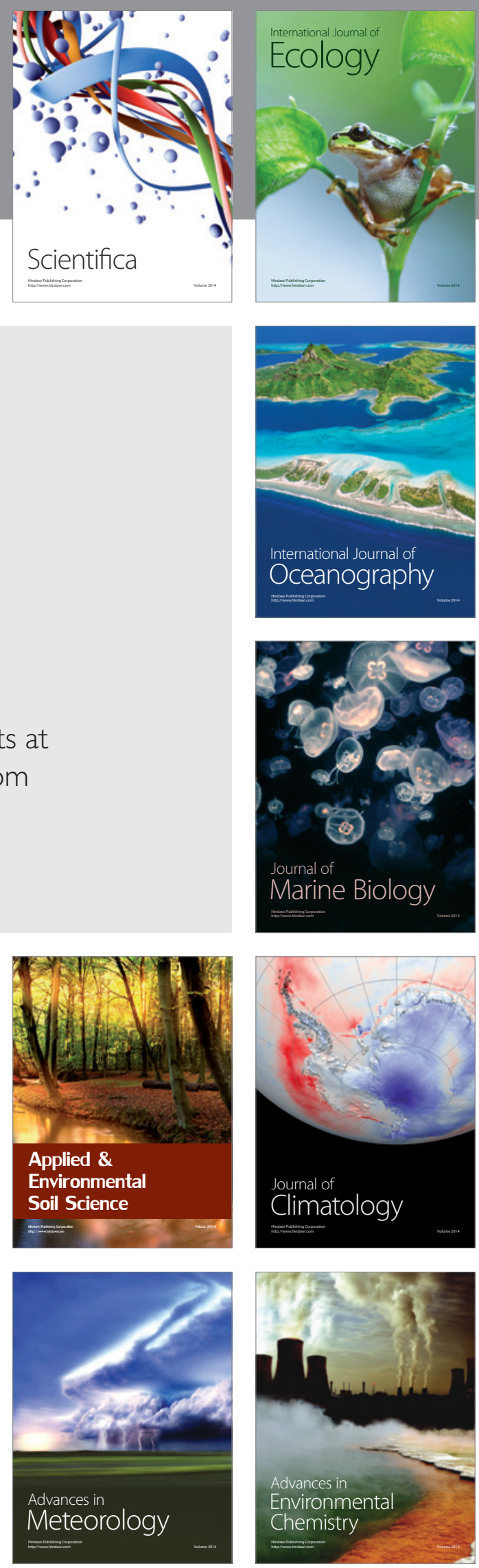